University of Minnesota Morris Digital Well

University of Minnesota Morris Digital Well

$5-2020$

\title{
Ritualized Performance and Community Identity: A Historical Examination of Drum Corps Competition in the United States
}

Denise Odello

University of Minnesota - Morris, odell059@morris.umn.edu

Follow this and additional works at: https://digitalcommons.morris.umn.edu/music

Part of the Music Performance Commons

\section{Recommended Citation}

Odello, Denise, "Ritualized Performance and Community Identity: A Historical Examination of Drum Corps Competition in the United States" (2020). Music Publications. 4.

https://digitalcommons.morris.umn.edu/music/4

This Article is brought to you for free and open access by the Faculty and Staff Scholarship at University of Minnesota Morris Digital Well. It has been accepted for inclusion in Music Publications by an authorized administrator of University of Minnesota Morris Digital Well. For more information, please contact skulann@morris.umn.edu. 


\title{
Ritualized performance and community identity: A historical examination of drum corps competition in the United States
}

Denise Odello

University of Minnesota Morris

Denise Odello is an associate professor of music at the University of Minnesota Morris. The focus of her research has been on musical ensembles that enjoy strong enthusiast support, such as British brass bands, American drum and bugle corps, and collegiate marching bands. Her recent work examines community musical ensembles in rural settings. She has published work in journals such as Popular Music and Society and Nineteenth Century Contexts.

Contact: University of Minnesota Morris, 600 East 4th Street, Morris, MN 56267, USA. E-mail: odel1059@morris.umn.edu

(C) Odello, 2020. The definitive, peer reviewed and edited version of this article is published in International Journal of Community Music, volume 13, issue 1, pages 65-79, 2020 , https://doi.org/10.1386/ijcm_00010_1.

\begin{abstract}
What structures bind musical communities that reach over distances? This article examines the musical community of youth drum corps in the United States and, in particular, the changing performance practices at competitions over time and how those changes influence the identity of the community. Drum corps is a community that exists
\end{abstract}


over increasingly greater distances, yet the identity of this musical community is strong. An important site for discovering this communal identity is in competitive performance. Drum corps performances are strictly regulated because of this competitive context, and the values seen in those competitive regulations reflect the identity of the community. Ritual theory helps to examine the mechanisms by which members of this musical community renegotiate these identity values over decades. This article discusses shifts in performance practices such as instrumentation, repertoire and motion, all of which are reflected in changing competition judging guidelines. Ritual theory is used to understand how members of the drum corps community understood the implementation and official recognition of these changes in competitions as changes to the community's identity.

Keywords: community identity, ritual, musical competition, marching band

Musical recreation in a group can happen in a community setting and create a distinct and shared sense of community among participants. While that community may be located in a specific place and time, a shared pastime such as making music can stretch the notion of 'community' even further. Building on Benedict Anderson's concept of imagined communities (Anderson 1983: 6-7), Kay Shelemay argued that our idea of community, and the musical practices these communities embrace, must be broadened to consider those held together by the musical practices themselves (Shelemay 2011: 357-60). One example of a musical community tied together by practices and values rather than geographic proximity is youth drum corps. In the United States, teenage and young adult participants present shows that feature music performed on primarily brass and 
percussion instruments as well as marching in diverse formations on a field. These groups emerged from outside of traditional educational setting. They were initially situated in specific communities with participation from local youth, and were connected by a shared military identity, influenced by associations with veterans' organizations. Over the twentieth century, however, the identity of both community and musical practices changed.

When changes have occurred historically in drum corps practice, there has been conflict between traditionalists and innovators. Competition became the primary site for contention within the drum corps community. How can we understand what is at stake for audiences and participants in changing musical and marching styles in competitive performance? Members of the drum corps community have found the changes in performance practices to be either representative of or an attack on their musical and community identity.

The theoretical lens of ritual practices is useful in this context, because this conflict occurs within the rigidly defined structure as drum corps competition. The formality and prescribed nature of competitive drum corps performance contexts, as opposed to less structured performance contexts that are more typical for other musical ensembles, means that new performance practices, and the changing values that they represent, must be dealt with directly by members of the community. Competitive musical settings like drum corps require the musical community to articulate their values explicitly to assess performances. Perspectives from ritual theory examine how ritual practices reflect the negotiation of these values; because musical competitions articulate the values of their musical community, the musical competition itself becomes the site for 
this value negotiation. The purpose of this article is to use the concept of ritual to understand the drum corps competition as a site for challenging community values through transforming stylistic practices, as well as the nature of the community conflict that arises from new performance styles. These changes in performance practices reflect changing community values on a larger scale.

\section{Definitions and literature}

Youth drum corps, as represented by Drum Corps International (DCI) and affiliated ensembles, is a competitive activity where participants develop musical and marching performances over a late spring and summer season. Structures of judging criteria either established by DCI or closely imitating DCI scoring guidelines inform these performances, so they are designed, at least in part, to be successful in competition. The performance practices and corresponding competition judging categories are derived from military traditions, similar to other American marching band practices (a brief history of the development of drum corps appears later in this article).

The modern iteration of drum corps is descended directly from youth groups and still promotes education as a primary goal of the activity (Drum Corps International). Participants must be between the ages of 13 and 22. Participants, mostly high school and college students, engage in auditions and training in the winter and spring sporadically. During the summer, the ensemble and staff travel together, training and performing their approximately twelve-minute show in exhibitions and competitions. These shows include special musical arrangements, generally around a theme, and elaborate marching drills to be performed on a football field. The instrumentation of the groups was initially derived from military instruments. A corps typically includes valved brass instruments with front- 
facing bells, marching percussion and grounded percussion (chimes, keyed percussion, etc.) in a designated area on the spectator side of the field known as the pit. Corps will perform in multiple local and regional competitions, hoping to qualify for the World Finals held in August in Indianapolis.

How does the drum corps community fit the definition of a musical community? Shelemay notes that the word 'community' acquired its connotation of geographic proximity until the twentieth century and that the Oxford English Dictionary definition of the term links the idea of community to a specific location (Shelemay 2011: 356). Drum corps are not primarily organized geographically, even though each group is based out of a particular place. Participants will often travel to participate with a corps, which makes these geographic relationships even more distanced. Drum corps are found in multiple locations around the United States. However, there are concentrations in certain regions, such as the upper Midwest around Wisconsin and northern Illinois, and northern California around San Francisco (Google 2017).

The community has participants who have varied positions and roles. In addition to the teenagers and young adults who perform in the ensembles, there are also directors, coaches, arrangers, drill designers and other staff who are involved with preparing performances. The organizer and adjudicators who run competitions are an integral but often separate group. Additionally, the community is not limited to current participants; past corps participants often continue to be part of the community, participating in distinct ways, such as spectators and commentators.

Shelemay's concept of community more appropriately reflects the nature of the drum corps community, which has broadened beyond specific physical locations and 
been construed in a variety of ways, not all of which use the term 'community' (Shelemay 2011). She offered the following definition: 'A musical community is, whatever its location in time or space, a collectivity constructed through and sustained by musical processes and/or performances' (Shelemay 2011: 354). This definition emphasizes the role of the musical activity itself. In drum corps, competitive regulations further codify these musical practices; there is limited musical activity outside of the competitive realm. Competition, therefore, strengthens the ties of this community, both in disparate locations and from past participants into the present. In contrast, Victor Turner's idea of 'communitas' focused on the relationship between individuals within the community (Turner 1969: 96). Many scholars, including Shelemay, acknowledge this essential element of group musical performance. Thomas Turino focused on this aspect of musical ensembles, saying that 'Through moving and sounding together in synchrony, people can experience a feeling of oneness with others' (Turino 2008: 2-3). As a precision marching musical ensemble, drum corps are focused on this synchrony, thus emphasizing these interpersonal connections that form communitas. As these synchronous actions are shaped by competitive regulations that change slowly over time, interpersonal relationships can be stretched to include past participants in drum corps. Past participants will continue to recognize performance practices because competition regulations keep change to a minimal controlled pace; past participants generally react negatively to change when it does occur.

The element that connects this community is the musical activity itself; the competitive nature of the activity shapes the performance practices to such an extent that any member of the drum corps community can recognize elements from drum corps with 
whom they are unfamiliar. In this light, this communal entity may be better viewed as one of Anderson's imagined communities, where the shared tradition of competition links participants and spectators alike in a 'deep, horizontal comradeship' (Anderson 1983: 7). This community structure is also akin to Turner's communitas, which emphasized a 'generalized social bond' instead of a specific location in the construction of community (Turner 1969: 96). Turino might call the drum corps community a 'cultural cohort' because it is the activity itself that holds the community together. However, he has not often used the term in such a geographically displaced way (Turino 2008: 95). The internet has strengthened community bonds with online publications and discussion forums, allowing participants and spectators to weigh in on corps' programs for the season or specific performances. Performances themselves, however, are generally not found online due to copyright restrictions. All of these elements of musical community and communitas - a group joined by common musical practices, and individuals joined to each other through group performances - are strongly present in drum corps practices. These shared musical practices and group performances are perhaps reasons that the community is so closely tied together, and why so many performances make references that are directed at community members rather than a more general audience that may attend a drum corps competition.

Ritual is often a critical element of a community, typically serving to reinforce beliefs. There have been volumes of scholarship produced on religious ritual in anthropology; the study of sacred rituals is part of the earliest anthropological inquiry. Creating a theoretical framework for understanding these rituals has been a more recent endeavour, with the work of scholars such as Turner $(1969,1979)$ and Catherine Bell 
$(1992,1997)$ providing foundational frameworks that are useful in this context. Bell identified three theoretical descriptions of ritual. The first frames ritual as an action that expresses or acts out belief systems, while the second contends that ritual, in dealing with these two elements of belief and action, attempt to reconcile them. Her third approach, which Bell credited primarily to Turner, builds on the reconciliation of thought and action by placing them in a community construct, where the ritual also serves to mediate competing demands of the community and formal social order (Bell 1992: 26-27). In a drum corps context, I argue the tradition itself is the belief system, and the judging criteria for performances, along with the performance practices themselves that realize those criteria, are the actions that express those beliefs. Values such as military tradition, technical ability, precision movements and, more recently, creative interpretation are all valued in judging criteria and therefore made primary in performances. These values have changed over time, and competition criteria and performance practices change have reflected those changes. Changes in the drum corps community over the twentieth century in the United States has reflected changes in youth culture. As Turner might have articulated it, performance judging criteria had to change somewhat to reconcile the changing demands of the community and the existing competitive tradition, the 'social order' of drum corps.

In such a carefully structured activity where the performance is the primary site of involvement for the community, it is logical that this same site became the focus and location of this conflict. In Turner's words, what occurred was a 'social drama', where a course of action is taken in the wake of conflict within a community. Turner stated that 'a social drama is initiated when the peaceful tenor of regular, norm-governed social life is 
interrupted by the breach of a rule controlling one of its salient relationships' (Turner 1979: 83, original emphasis). In 1971, the performances described above were viewed as breaches of accepted tradition by the veterans' organizations, while new performance modes became meaningful innovations for the participants and instructors. Turner called this type of inter-community conflict a 'crisis' that threatened to split the community unless 'redressive means' were undertaken. Redressive action involves some form of ritualized action in a formal setting. This process leads to one of two concluding actions: 'reconciliation of the conflicting parties... [or] consensual recognition of irremediable breach' (Turner 1979: 83). This moment of crisis in the youth drum corps community led to the formation of Drum Corps International in 1971. This conflict was primarily between the military values of the veterans' organizations that had organized the youth activity for decades, and the newest generation of participating youth, as well as the young instructors working with them. Veterans' groups saw youth drum corps as a way to promote military values. In contrast, the younger participants saw artistic expression as much more important and wanted to broaden the marching and musical practices of drum corps shows. As I will detail below, formal mechanisms to negotiate performance criteria - and, symbolically, community values - were unable to resolve the widening differences between different parts of the youth drum corps community, mainly the ensembles and veteran competition organizers.

While there are several discussions of drum corps history aimed towards participants and enthusiasts, there is less scholarly literature available on drum corps as an activity. Jonathan Ritter is the only author who has examined the drum corps performance and season as a ritual activity (Ritter 2001). At the time of his writing, 
however, there was little cohesive historical information published on the activity, so he had to draw primarily on his personal experiences. In later work, Dennis Cole worked to identify both social and musical elements of drum corps, tracing both the social values and the diverse musical profile of the activity (Cole 2009). Cole noted the educational origins of drum corps and looked for those connections in current practices. His work examined shifts in drum corps practice, primarily through a conflict between traditional and innovation, as well as how the creation of DCI as an organizational body changed the social orientation of the activity. Additionally, Cole provided an insider view of drum corps by using a specific organization, the Bluecoats, as a case study. His ethnographic and quantitative work creates a social picture of drum corps participants and their perceptions of the activity. Janie Leigh Vance made the connection between drum corps and educational practice more explicit in her work, examining how her own experience as a participant in drum corps shaped her assumptions about music education, and what educational values were represented by the drum corps tradition (Vance 2014). The work I propose here differs from these examples primarily by using performance practices, both in terms of music and movement, as the starting point for discussions of community values. This work is also be more specifically focused on competition as the site for the negotiation of those performance practices and community values using ritual theory to understand how these changes occur.

\section{Drum corps history through a ritual lens}

To fully understand the ritual nature of drum corps performance, we must establish the underlying 'beliefs' of the community, or the purpose of the activity. To do this, we must return to the origins of drum corps as a youth activity, or more precisely, to the adult 
precursors of the youth activity. Veterans' organizations such as the Veterans of Foreign Wars (VFW) and American Legion initiated the formation of civilian drum corps. They did so after the end of First World War to maintain social networks that had emerged among service members during their deployments. The organizations were also designed to maintain public awareness of the veterans and their concerns, in particular, patriotic sentiment in the populace at large and support for returning veterans. The VFW was a conglomeration of two veterans' organizations originating in 1899 and adopting the common name of Veterans of Foreign Wars in 1914; the American Legion emerged in the wake of First World War in 1919 and counted more than a million members by Second World War (Rumer 1990: 236).

Drum and bugle corps had existed before 1900 as a corollary to the golden age of bands in the United States when Patrick Gilmore and John Philip Sousa led the way for community bands in many towns. Earlier on the military field, bugles or trumpets were the primary signalling device for troops, having by the end of the nineteenth century replaced earlier fife and drum groups. Bugles themselves were displaced as signalling methods by the end of First World War, having been replaced in military operations by more efficient electronic means of communication. The newly superfluous instruments provided the means for such ensembles in the civilian veterans' organizations. The bands were mainstays of local life, appearing in parades and local celebrations, thus keeping the groups in the public eye. The ensembles were especially active at national conventions, where the 'Big Parade' featured the entire body of delegates and marching ensembles attending the meeting. One report of the 1933 parade in Chicago described the event as more than nine 'glorious' hours of 'drum corps, more drum corps and still more drum 
corps - interspersed with bands, floats and marchers'. The 1937 parade in New York was described as 'an unforgettable spectacle that lasted eighteen hours - 150,000 marchers, over 500 bands and drum corps' (Osherhoff and Zinko 2002: 7-8). In 1921, these assembled drum corps were judged, thus initiating drum corps competitions (Osherhoff and Zinko 2002: 40).

Veterans' groups soon initiated junior groups. First World War was supposed to be the 'war to end all wars', so the groups actively passed on the military tradition to the next generation who would presumably never serve in a conflict of that magnitude. Local posts supported a wide variety of youth activities, including Boy Scout troops and baseball programmes. Junior drum corps were a natural extension of such recreations, and music became the vehicle for the inculcation of patriotic and military values. In this way, youth drum corps gained the educational component that still marks the activity today. Other youth organizations, such as Boy Scouts, Catholic Youth Organizations, Elks Lodges, Police Athletic Leagues and fire-fighter organizations also started groups modelled on the veterans' corps. The popularity of drum corps grew to the point that several local and regional competitions were held. At the same time, both the Legion and the VFW organized national competitions around their national conventions, first for the veterans and then for youth groups. The VFW initiated a national competition for junior corps in 1936, and the American Legion first held junior competitions in 1937.

The drum corps competition can be read as a ritual in the drum corps community because competition, especially the World Finals, is the focus of the community and reflects community values through performance regulation. In order to see elements of ritual in drum corps competition, however, we must first consider how scholars define the 
aspects of ritual. In her classification of different types of ritual, Bell finds common elements to be that the 'action is primarily communal, traditional (i.e., understood as carrying on ways of acting established in the past), and rooted in beliefs of divine beings of some sort' (Bell 1997: 94). Musical competition, as embodied in drum corps competition, follows many of these trajectories. Most obviously, drum corps competitions have a strict and complex set of regulations, primarily concerning the style of performance that takes place within the ritual form of the competition. Regulations carry on from year to year with the intention of keeping the activity traditional, or at least linking it to past iterations of the activity. In the early competitions, military musical practices were prominent because junior drum corps were supposed to pass those values on to participants. Performance regulations are only altered with lengthy discussion, where participants strive to reconcile the desire to adapt with previously accepted performance style, to keep 'carrying on ways of acting established in the past', and the values that were attached to those actions. The rigid structure of musical competition maintains consistent musical practices more effectively than a more loosely structured or spontaneous musical activity. This structure links the action, or performance practices, to belief, or the value structures that form the basis of regulations shaping performance practices. In the case of drum corps, those values are tied to the military and educational roots of the activity.

The first junior drum corps competitions were highly regulated events where the beliefs of the community, military and patriotic values were acted out through specific performance elements. Judging criteria articulated those military elements explicitly in some examples. Instrumentation was restricted to military instruments; for brass, this 
initially meant soprano bugles in $\mathrm{G}$ with no valves, while for drums, this meant marching percussion. The repertoire of the corps was limited to patriotic pieces and marches. The competitions moved from the street parades to football stadiums, a location already established as a venue for marching and pageantry. This type of venue allowed groups to march in a block formation as in a parade, from one end of the field to the other. The time that each ensemble took to traverse the field was strictly limited to approximately eleven to thirteen minutes on the field, depending on the competition. Tempo for performances was limited to typical march tempos; the acceptable range was between 128 and 132 beats/steps per minute. While other musical elements were accounted for in the adjudication of the groups, the context must be considered. Most youth who joined the groups could not read music and had no experience with the instruments they were assigned, especially because these were military instruments that were not used in schools. The instructors of these instruments were usually corps alumni or veterans who often had minimal musical literacy themselves (Sward 2002: 98). The repertoire did not demand technical proficiency; patriotic fervour and precision movement were more central to the performance and more integral to acting out the beliefs of the community.

A close examination of the categories and method of adjudication further demonstrates how community values were enforced in performance actions. Scoring used a military 'tick' system; groups began with full scores in each category, called a caption, and then were penalized for infractions. While point totals varied slightly between competitions, early judging sheets and guides to scoring for groups looking to establish local competitions are extant. One example by Sam Rowland published by the Slingerland company, a percussion manufacturer, in 1929 provides a useful example (see 
Table 1; Atkinson and Close 2003: 67). An inspection of an ensemble's uniforms before they stepped on the field was typical. The Cadence caption monitored the tempo of the marching. Marching and Manoeuvring $(\mathrm{M} \& \mathrm{M})$ was concerned with the precision details of marching: intervals between men on the field, distances between ranks and files, conformity of movement, 'military bearing', etc. Other captions were more musical but still contained military elements. The bugle adjudication considered factors such as tone and musicality, but also judged the uniformity of playing positions. Drum adjudication monitored both the precision of performance and visual elements, such as the height and angles of the sticks. The tick system reinforced the military practices of the drum corps, as it discouraged innovation and experimentation by focusing on errors in execution.

Table 1: 100-point judging scale from 'A System of Judging Drum and Bugle Corps' (1929).

\begin{tabular}{|l|l|}
\hline Caption & Points \\
\hline Inspection & 15 \\
\hline Cadence & 10 \\
\hline Marching and manoeuvring & 35 \\
\hline General playing: bugles & 20 \\
\hline General playing: drums & 20 \\
\hline Total & $\mathbf{1 0 0}$ \\
\hline
\end{tabular}

While musical competitions like drums corps contain many aspects of ritual, a significant way that they diverge from typical anthropological definitions of ritual is that there is no religious component, or deity intervening in some way throughout the process. In their discussion of competition and drama as secular ritual, Mary Gluckman and Max Gluckman prefer the term 'ceremonial' for behaviour that is formalized and has 
traditional, recurring elements (Gluckman and Gluckman 1977: 230-31). Those authors acknowledged that performance and ritual 'may both express moral rules, [but] only ritual affects the fate of the participants through its further effects on mystical powers' (Gluckman and Gluckman 1977: 240). Turner, to whom Gluckman and Gluckman were directly responding, did not have this concern. In his later works, such as From Ritual to Theatre: The Human Seriousness of Play (1982) and The Anthropology of Performance (1988), Turner viewed the symbolic action of ritual as performance, moving to see all performance as having some element of this symbolic action. Further, he found that performance could have the same impact as ritual, 'that cultural performances are not simple reflectors or expressions of culture or even of changing culture but may themselves be active agencies of change' (Turner 1988: 24). Even without the supernatural component, the structure of drum corps competition and frequent invocation of tradition and attendant values make ritual a useful perspective to further understand the importance of performance guidelines for participants. As Turner argued, the ritual of performance competitions in drum corps activity did not merely reflect cultural changes. It became an agent of change for the ritual of performance, or a space where participants challenged cultural/performance norms and values so that the ritual would more directly reflect the community.

By the end of the 1930s, youth drum corps competitions, along with standard judging criteria, were established. The adjudication emphasized military elements over other artistic avenues. Since competition was the primary performance context, and these performance values were codified in the judging criteria, any change - or challenge to these values - would come slowly and with debate. It was not possible for community 
authorities, competition judges, to ignore challenges to established performance practices because they were required to evaluate all performances. When we consider both musical and visual performance practices in this ritual lens, changes become symbolic of other forces moving in the community. With the directions that youth culture would take in the second half of the twentieth century in the United States, challenge and change were inevitable, if slow in coming. The activity grew throughout the 1940s and 1950s, although national competitions were suspended during Second World War. By the return of national competitions in 1946, many groups had adopted single-piston bugles as well as baritone bugles, which slightly expanded harmonic possibilities (Atkinson and Close 2003: 100). Visual practices began to change as well slowly; in addition to block formations, corps began to move more on the field, although always in straight lines. Repertoire began to include more Broadway selections in addition to the marches and patriotic tunes that were already common. All of these early shifts moved away from a strict military tradition to provide more artistic possibilities but were not so drastic as to violate judging criteria. The expansion of the repertoire, for example, was still specifically American.

The late 1960s marked a crucial time for American youth as a distinct youth culture began to emerge. It follows that a youth activity like drum corps would confront these cultural forces. At this time in American society, youth culture increasingly began to reject military imagery as drum corps continued to promote military or nationalist performance styles. Drum corps competitions became a site for challenging these values. Reacting to changes in youth culture, the American Legion added uniform requirements such as hair length that did not exceed the collar and trimmed facial hair to inspection 
sheets in the 1960s. At the VFW National competition in 1971, as the Madison Scouts made their final pass in front of the judges after their performance, several corps members removed their hats to reveal long hair that had been hidden previously under close-cropped wigs (Waerzeggers 2010: 35). Another example of the clash of youth and veteran cultures occurred in 1972. That year, the Garfield Cadets performed a show entitled 'No More War'; the performance included a simulated battle where the corps 'died', and a peace sign formation on the field, infuriating some of the veterans adjudicating the event (Sward 2002: 119-20). These shifts were prompted both by the participants in the corps and the increasingly younger instructional staff. The staff who worked with drum corps in the late 1960s did not have the military experience and minimal musical training that instructional staff previously had; instead, by 1971, an increasing number of instructors held or were pursuing degrees in music and the arts (Waerzeggers 2010: 30). These instructors viewed drum corps ritual very differently: they saw creative expression as the purpose of the ritual, rather than a connection to military values and tradition.

Two shows performed in 1971 summarize this shift in the perceived underlying purpose of drum corps performance. Many corps chose to push creative boundaries with the use of different repertoire, costumes, dancing, and props to create thematically integrated performances that valued creative expression over military imagery (Waerzeggers 2010: 29). The show performed by the Chicago Cavaliers and Madison Scouts were particularly noteworthy because both corps were known for being more traditional in approach. The Cavaliers were known for military precision, while the Scouts had been slightly more focused on entertaining presentations. In 1971, the 
Cavaliers presented a circus-themed performance, including elements such as a clown and a juggler. The Scouts show was centred on Alice in Wonderland and included a girl (the daughter of the director) and other characters skipping and dancing on the field. While such elements like dancing and costumes in the Scouts' show had not been expressly forbidden, their blatant non-military orientation was contrary to the traditional values conveyed through competition. The person who oversaw VFW youth drum corps, Anton Schlechta, a First World War veteran with limited musical experience, intimated as much in his annual spring release to the drum corps community through various drum corps periodicals. He decreed that costumes, dancing and 'general clowning around' would not be tolerated (Waerzeggers 2010: 15). Some audience members had similarly strong reactions to this new performance style. One drum corps traditionalist complained about the Cavaliers show in particular:

$[\mathrm{H}]$ ere is one of the all-time winners, going so Mickey Mouse you wouldn't believe it [...] There are people out of uniform, equipment on the ground, whistles blowing, boys dancing, girls dancing, a little girl running down the sidelines bowing to the people, I mean a little girl about 8 years old, a whole corps running from one formation to another, acrobats, jugglers, clowns, horses, balloons, rockets, tumblers. All we're missing is the jackasses that wrote this garbage.

(Waerzeggers 2010: 29)

The scores for these performances varied somewhat, as the judging panels were becoming younger and more interested in the theme show, or a more entertainmentoriented approach. The veterans who were still organizing the events and determining the overall rules were the most displeased by these performances that strayed from expressing military values. 
Adjudicators and other drum corps competition authorities would have to recognize these stylistic shifts and account for them in judging sheets. While a slow expansion in repertoire may not be judged explicitly, instrumentation, tempo and visual elements were typically part of a corps' score. Any change to regulations for veterans' competitions would have to be approved by a regulating body primarily made of veterans, such as the National Contests Supervisory Committee that oversaw American Legion contests at the mid-century. Drum corps directors and others could propose rule changes to be considered by such a committee. Still, the veterans had the final say. They rejected the majority of proposals, thus attempting to preserve the original intent of the ritual by retaining military rather than creative artistic values. The push against proposed changes in artistic directions was substantial. One corps director, who had attended the committee's meetings for several years in efforts to change these regulations, said the sessions were 'a haven of politicking, cronyism and absolute authority, and [showed] a plain disregard for drum corps individuals who had accomplished the impossible throughout the country on the American Legion's behalf' (Waerzeggers 2010: 17). The VFW was even more difficult to innovate within, as a single person controlled all drum corps competition. In his position overseeing youth drum corps activity, Schlechta could make broad changes at almost any point, especially concerning performance elements that were not addressed directly in competitive regulations (Vickers 2014). Such a system allowed for only small and gradual change and the power to make those changes was decidedly concentrated on one side of the veterans-drum corps dichotomy.

A shift in instrument technology provides an excellent example of how competition regulations and the process of negotiating performance style slow change; in 
this case, change still occurred. Traditional military bugles used by corps were in the key of $\mathrm{G}$ and had no valves or pistons, thus limiting the notes they would be able to play. The single-piston bugle had been in use by the US Marine Corps since 1938, so it could be argued that it was not, strictly speaking, breaking with military tradition for youth corps to adopt these instruments (Pirtle 2002: 74). However, evidence from the period suggests that performers knew that these changes were contrary to accepted practices. For example, instrument catalogues from the late 1920s and early 1930s that featured singlepiston bugles noted that the piston was positioned horizontally instead of vertically on the instrument to allow the performer to continue to hold the instrument with one hand, as was typical of military practice. This placement also had the benefit of effectively hiding the piston from competition judges. The new technology did not stay hidden long; until single-piston bugles became accepted in the 1940s, the American Legion competition required corps that had single-piston instruments also to have a valve lock to prevent the use of the piston during competition (Pirtle 2002: 73).

In the context of this moment in drum corps history, a possible redressive action would have been formalized negotiations, via the established rule-making bodies, to revise competition regulations, something that would happen later in DCI's existence as different performance trends emerged. At this time, however, Schlechta's more authoritative approach indicated to corps members and instructors that such a negotiation was not likely. Schlechta further reiterated the point in the manager's meeting immediately preceding the VFW finals in Dallas that year. William Howard and Don Warren, directors of the Scouts and Cavaliers respectively, later identified that moment as a pivotal one, confirming the idea that drum corps needed to separate themselves from 
the veteran's organizations (McCormack 1998). DCI emerged within a year as the new organizational body for youth drum corps. Initially, the new organization of thirteen drum corps attempted to negotiate with veterans' organizations to preserve the popular competitions, an additional attempt at redress in a formalized manner. DCI would only do so with the veterans' organizations accepted a specific list of judges who were sympathetic to moving in new artistic directions; the veterans' organizations were simply not willing to move away from the primacy of military performance values (Waerzeggers 2010: 41). In 1972, DCI sponsored its first national drum corps competition, thus cementing what Turner would refer to as an irremediable breach. As more corps began to participate in DCI events, the events sponsored by veteran's organizations became less relevant and eventually discontinued.

This shift was not initially universal, nor was it universally accepted. Some commentators felt that the increasing artistic ambition on the part of the drum corps staff was leaving some members behind. The new competitive field was increasingly national and occasionally international, requiring more resources. Successful corps had to grow larger and draw members from increasing distances, aided by the new mobility of teenagers and young adults and their desire to be a part of a competitively successful group (Acheson 2013). Summer travel became longer and more involved as corps needed to travel to more distant DCI competitions rather than more local veterans' competitions, demanding increasing investment both of time and money from corps members. Competition for members from larger corps and steep travel demands were too much for many smaller corps, and some began to fold. Many involved with drum corps objected to this shift from local activity to a more national scope immediately. In August of 1973, 
George Oliviero wrote in a letter to the editor of Drum Corps News, 'Wow! Where is this activity going? Isn't it possible for DCI corps in particular to get together and plot a sensible, sane schedule? Let's stop and give some thought to our kids. Let's not use them only as a means to our own ends and glory [...]' (Oliviero 1973). The shift away from a military tradition was also a point of contention, as Dick Blake noted in an editorial appearing only two weeks later: 'Where have the Inspection and Military Bearing gone? These items that have put drum corps head and shoulders above any marching band in the world?' (Blake 1973).

Despite these misgivings on the part of some, the split pushed forward; neither side was willing to take redressive action in the context of ritualized performance. To fully meet the goals of artistic freedom within DCI, however, the template of regulations that drum corps had been operating with under the veterans' organizations were slowly revised and revisited through Rules Congresses, made up of directors, instructors, adjudicators, drum majors and other constituencies. Drum corps and their representatives can propose rules changes to be voted on by members of the group. Through this process, judging criteria were made increasingly standardized, while still operating on the military ‘tick’ system. The tick system was eventually abandoned in 1984 in favour of a built score that totalled 100 possible points. General effect (GE) continued to be a significant aspect of scoring; in 1988, it was heavily weighted, worth 55 or 100 possible points between brass, percussion and visual elements (Pilato 2000; Atkinson and Close 2000: 71). The system continued to shift as DCI tried to accommodate the increasingly ambitious and varied performances of the corps. In 2000, the system adjusted yet again, with 40 points for GE. The colour guard, whose activities had vastly expanded from a 
simple presentation of the colours by this time, was finally recognized in a separate caption with other visual elements.

In contemporary drum corps practice, DCI continues to hold Rules Congresses to adjust competition regulations as the medium continues to change; after voting at the 2018 Rules Congress, these meetings have shifted from biennial to annual events (Drum Corps International.org 2018). This process continues to result in several significant changes to drum corps practice. For example, any type of keyed brass with forwardfacing bells were allowed as of 2000, and then any kind of brass instrument in competition, such as trombones and French horns, were allowed in 2014 (Maher 2011: 16; Geli 2014). In 2003, amplification was allowed on the field, the first time that anything electronic had been allowed in performance, and in 2009 electronic instruments such as synthesizers were permitted (Maher 2011: 28). This process has allowed for different viewpoints about the meaning and purpose of drum corps as an activity, and the competition as the focus of that activity, to reconcile differences and preserve ritualized performance. More than forty years into the existence of DCI as an organization, this process has prevented further splits within the drum corps community, even as proposed and enacted rules changes continue to be debated online and at Rules Congresses. These debates and the processes that formalize procedures for change allow drum corps performance to be rooted in tradition, continuing with links to the past even as the activity changes, and to remain communal through large group participation. While some competitions in the 1960 s were sites for contesting, allowing ritual to be an agent of change, Rules Congresses now provide a process for change to occur outside of the ritual 
setting. However, some drum corps will forego competitive success to push boundaries during competitive performance.

The ritual of competitive performance continues to provide members with Turner's concept of communitas with their corps and other drum corps, thus making DCI competitions an enduring form of performed ritual. While the style of the shows themselves may be slowly altered via Rules Congresses, the shape of the ritual itself persists. Competition is still the primary site for performance, and many of the particular stylistic elements that have continued in drum corps performance - the format of the marching presentation, most of the instrumentation, uniformity on the field, etc. - are still reflective of the activity's early origins with veterans' organizations. The Rules Congresses seem to have had the overall effect of accelerating change compared to previous eras, and these changes are usually instigated by drum corps staff and participants. Drum corps observers and former participants continue to express concern that changing performance practice changes are changing the fundamental values, as they perceive them, of drum corps. In this way, the inter-community conflict now tends to occur between former and current participants more than between current participants and competition organizers. This commentary has not led to any other breaks in the drum corps activity. Still, it does speak to the value that members of the drum corps community attach to what appears to be a minor stylistic decision, such as the use of a trombone as a solo instrument. Performance practices, as enacted in drum corps competition, are seen as symbolic of larger community values. The drum corps competition continues to be the primary site for the entire community and continues to express community values through performance practice, even as these values change. 


\section{References}

Acheson, Dan (2013), Personal interview with author, Indianapolis, IN.

Anderson, Benedict (1983), Imagined Communities: Reflections on the Origin and Spread of Nationalism, London: Verso.

Atkinson, Christopher and Close, Alison (2003), 'And now the scores...The art and science of drum corps judging', in S. Vickers (ed), A History of the Drum and Bugle Corps, vol. 2, Madison, WI: Sights and Sounds Inc., pp. 66-71.

Bell, Catherine (1992), Ritual Theory, Ritual Practice, Oxford: Oxford University Press. (1997), Ritual: Perspectives and Dimensions, Oxford: Oxford University Press.

Blake, Dick (1973), ‘An editorial', Drum Corps News, 15 August.

Cole, Dennis (2009), 'What is a drum and bugle corps? Reinterpreting traditions inside the musical community', Ph.D. dissertation, Kent State University.

'Corpsrep.com: History preserved', http://www.corpsrep.com. Accessed 20 May 2018.

Drum Corps International (2014), 'About drum corps international: Mission statement', Drum Corps International.org, https://www.dci.org/static/about-drum-corpsinternational. Accessed 15 March 2017. (2018), '2018 rules proposal voting result', Drum Corps International.org, 6 January, https://www.dci.org/news/2018-dci-rules-proposal-voting-results. Accessed 21 July 2018. 
Geli, Elizabeth (2014), 'DCI's new 2014 rules', Halftime.com, 24 March, http://www.halftimemag.com/noteworthy/dci-s-new-2014-rules.html. Accessed 21 July 2018.

Gluckman, Mary and Gluckman, Max (1977), 'On drama, and games and athletic contests', in S. F. Moore and B. G. Meyerhoff (eds), Secular Rituals, Amsterdam: Van Gorcum, pp. 227-43.

Google (2017), 'DCI and DCA Map', Google, https://www.google.com/maps/d/viewer?mid=11IOg3mIaMTZ6dt7MJHmVK8C Dzpk\&ll=39.72178010994197\%2C-96.20472482499997\&z=5. Accessed 3 June 2019.

Maher, Erin (2011), 'The amplification controversy in drum corps international: Technological change and the meaning of tradition', Master's thesis, UNCChapel Hill.

McCormack, Larry (1998), When Drum Corps Was Really Drum Corps: A 50 Year History, DVD, Palatine, IL.

Oliviero, George (1973), 'Letter to the editor’, Drum Corps News, 1 August.

Osherhoff, Raphael and Zinko, Robert (2002), 'The big parade: The veterans organizations and the drum and bugle corps movement', in S. Vickers (ed.), $A$ History of the Drum and Bugle Corps, vol. 1, Madison, WI: Sights and Sounds Inc., pp. 1-62.

Pilato, Nikk (2000), 'Judge not, lest ye be judged: An examination of over 25 years of DCI judging', Marching Virtual Symposium, http://www.oocities.org/marchingresearch/pilsym00.txt/. Accessed 14 July 2018. 
Pirtle, Scooter (2002), 'The evolution of the bugle', in S. Vickers (ed.), A History of the Drum and Bugle Corps, vol. 1, Madison, WI: Sights and Sounds Inc., pp. 63-89. Ritter, Jonathan (2001), 'The summer music games: Drum and bugle corps as ritual', Marching Virtual Symposium, http://www.oocities.org/marchingresearch/ritsym01.txt. Accessed 21 June 2018. Rumer, Thomas (1990), The American Legion: An Official History, 1919-1989, New York: M. Evans and Co.

Shelemay, Kay Kaufman (2011), 'Musical communities: Rethinking the collective in music', Journal of the American Musicological Society, 64:2, pp. 349-90.

Slingerland Banjo and Drum Company (1929), 'A System of Judging Drum and Bugle Corps', Chicago, IL: Slingerland Banjo and Drum Company.

Sward, Rosalie (2002), 'The evolution of musical and visual design', in S. Vickers (ed.), A History of the Drum and Bugle Corps, vol. 1, Madison, WI: Sights and Sounds Inc., pp. $97-186$.

Turino, Thomas (2008), Music as Social Life: The Politics of Participation, Chicago, IL: University of Chicago Press.

Turner, Victor (1969), The Ritual Process: Structure and Anti-Structure, Ithaca, NY: Cornell University Press. (1979), 'Dramatic ritual/ritual drama: Performative and reflexive anthropology', The Kenyon Review, 1:3, pp. 80-93. (1987), The Anthropology of Performance, New York: PAJ Publications. 
Vance, Janie Leigh (2014), 'Findings from the field: A pedagogical and cultural study of the North American drum and bugle corps experience', EdD dissertation, Teachers College, Columbia University.

Vickers, Steve (2014), phone interview with author.

Waerzeggers, Nicholas (2010), Drum Corps International: The First Decade 1972-1981, Madison, WI: Sights and Sounds Inc.

Denise Odello has asserted their right under the Copyright, Designs and Patents Act, 1988 , to be identified as the author of this work in the format that was submitted to Intellect Ltd. 